ENTREPRENEURSHIP AND SUSTAINABILITY ISSUES

ISSN 2345-0282 (online) http://jssidoi.org/jesi/

2021 Volume 8 Number 4 (June)

http://doi.org/10.9770/jesi.2021.8.4(45)
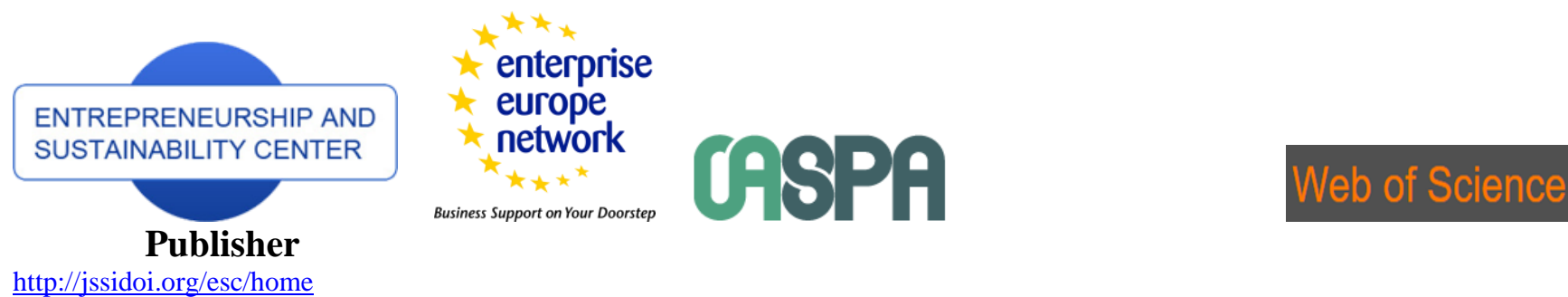

http://jssidoi.org/esc/home

\title{
AREAS OF SMALL BUSINESS DEVELOPMENT IN UKRAINE IN THE CONDITIONS OF EUROPEAN INTEGRATION
}

\author{
Kazimierz Pajak ${ }^{1}$, Viacheslav Volik ${ }^{2 *}$, Iryna Slovska ${ }^{3}$, Yuliia Lushchyk ${ }^{4}$, Hanna Tsyhanok ${ }^{5}$ \\ ${ }^{1}$ Institute for International Cooperation Development, 24-26/1 Kazimierza Wielkiego Street, Poznan, 61-863, Poland \\ ${ }^{2}$ Mariupol State University, 129a, Budivelnykiv Ave., Mariupol, 87500, Ukraine \\ ${ }^{3}$ National University of Water and Environmental Engineering, 11, Soborna str., Rivne, 33028, Ukraine \\ ${ }^{4,5}$ Sumy National Agrarian University, Gerasima Kondratyev str., 160, Sumy, 40000, Ukraine
}

E-mail: ${ }^{2 *}$ volik_v@ukr.net (Corresponding author)

Received 18 February 2021; accepted 7 May 2021; published 30 June 2021

\begin{abstract}
The relevance of the subject of this study is due to the situation and negative trends in Ukrainian small business, the importance and number of this type of business entities, and institutional constraints on business activities, which requires increasing its effectiveness and efficiency through sustainable development. The purpose of the paper is to develop theoretical-methodological foundations, scientificmethodical and practical recommendations for the development of small business in Ukraine. To obtain specific scientific results both general scientific and specific methods of study were used: a complex of economic-statistical and economic-mathematical methods of analysis and modeling. The state and tendencies of development of national small business were analyzed. Based on the obtained results the comparative analysis of specifics of small business in Ukraine was carried out. The strategic priorities of small business development of Ukraine were substantiated, which observance will promote growth of national economy and will allow to clearly identify necessary areas of support for small business entities in the course of development and implementation of programs of development of small business at various levels of management. The basis for the development of national and regional strategies for small business development should be not only regulatory and legal support, but also previous positive experience, in particular, on the implementation of strategic projects for small business development in leading European countries, regions and separate cities. The fact that in Ukraine small business is not yet given due attention, there is no clear concept and in fact the declared strategy of its development is not implemented, proves the need to develop small business and reflect this in the development of a strategy.
\end{abstract}

Keywords: small business; strategy; institutional constraints; development

Reference to this paper should be made as follows: Pajak, K., Volik, V., Slovska, I., Lushchyk, Y., Tsyhanok, H. 2021. Areas of small business development in Ukraine in the conditions of European integration. Entrepreneurship and Sustainability Issues, 8(4), 730-741. http://doi.org/10.9770/jesi.2021.8.4(45)

JEL Classifications: K22, L21 


\section{ENTREPRENEURSHIP AND SUSTAINABILITY ISSUES}

ISSN 2345-0282 (online) http://jssidoi.org/jesi/

2021 Volume 8 Number 4 (June)

http://doi.org/10.9770/jesi.2021.8.4(45)

\section{Introduction}

The experience of many countries around the world shows that small business should be seen as a driver of economic growth (Vial \& Hanoteau (2015); Vigliarolo (2020)). Effective development of small business creates the preconditions for solving the problem of employment and ensuring the welfare of the population. However, the activities and development of small business are more vulnerable to the impact of unpredictable market threats than those of large and medium-sized business entities.

All this, as well as the most significant (over $99 \%$ in Ukraine as of 2019) share of small entrepreneurs in the structure of economic entities of the national economy determine the relevance of development of methodological foundations and scientifically sound tools for effective implementation of small business development programs at all levels of management, taking into account the country, regional or sectoral variability of market conditions for doing business.

In 2019, in Ukraine there were over 1.8 million small business entities (of which almost $19 \%$ were legal entities), which generated $16 \%$ of GDP. $49 \%$ of all jobs in the country were created by small business entities. However, over the past ten years, employment in small business has decreased by almost $16 \%$, which was also caused by the lack of a balanced scientifically sound strategy for small business development and real practical measures for this development.

The above negative trends and the orientation of Ukrainian small business products mainly to the domestic market, despite the new opportunities and challenges related with globalization 4.0, accelerated development and use in business of information and computer technologies, artificial intelligence, etc., require development of not only new conceptual approaches in the theory of entrepreneurship but also practical recommendations, the implementation of which will improve the management of the potential of small business in Ukraine, will promote the intensification of innovative activities of small entrepreneurs in the process of building the national economy.

The urgency of the development of small business in Ukraine is evidenced not only by the need to increase the level of GDP generated by national small business entities, but also the low position of Ukraine in international rankings: 81st position of 137 in the global competitiveness ranking; last position in Europe and 135th position of 162 in the economic freedom ranking; 43rd position of 190 in the tax burden ranking; 126th position of 180 in the corruption perception ranking; 45th position of 203 in the globalization ranking; 47th position of 129 in the global innovation ranking; and 64th position of 190 in the doing business ranking. The improvement of these ranking positions, as well as the reduction of the unemployment rate in Ukraine, which in 2019 amounted to $8.6 \%$ and in the second quarter of 2020 reached $9.6 \%$, may, in particular, contribute to the progressive development and effective activities of small business entities, which are difficult to count on in the absence and/or low efficiency of implementation of the state, regional and non-state programs and measures for small businessmen.

\section{Literature review}

Scientific thought distinguishes between two main models of entrepreneurship: classical and innovative. The classical model is focused on the most efficient use of all types of resources of a business entity. The model involves the assessment of available resources, the study of opportunities to achieve the goal, the practical implementation of opportunities, which can provide the maximum economic effect from the use of resources (Galvão et. al (2020)). 


\section{ENTREPRENEURSHIP AND SUSTAINABILITY ISSUES}

ISSN 2345-0282 (online) http://jssidoi.org/jesi/

2021 Volume 8 Number 4 (June)

http://doi.org/10.9770/jesi.2021.8.4(45)

The innovative model is focused on the active use of the latest management, technical, technological and socioeconomic solutions and provides for (Senapati \& Ojha (2019)): goal setting, study of the state of the environment and the search for additional opportunities, comparative assessment of available resources and identified opportunities, search for external resource sources, analysis of the competitive environment, implementation of tasks in accordance with an alternative option, which is followed by the largest positive economic effect.

Ahsan (2020) giving a comparative description of classical and innovative models of entrepreneurship, as the main criteria for comparison uses the following: the purpose of business activity, means to achieve the goal, variability of actions, attitude to risk, response to changes in the economic environment, incentive system.

Based on IDEF0 methodology, Kimmitt \& Munoz (2017) developed a functional model of business activation, which illustrates the structure of business processes, their relationships, provides for an assessment of the optimal organization of interaction between different business processes and within each of them. The suggested model takes into account the influence of external factors, coordinated interaction of public authorities, support and promotion of business in the context of the function of motivation.

In the light of dynamic changes in the environment, current challenges and recent trends in the national economy development, it is considered objectively necessary to digitize the latter, to develop digital infrastructure, stimulate the domestic market of production, use and consumption of digital technologies (Karlan \& Valdivia (2011)).

Digitalization as an effective mechanism of economic growth will allow to implement the accelerated scenario of digital development of society while removing existing barriers, motivating business, implementing state projects of digital transformations, creating and developing digital infrastructure, developing digital entrepreneurship and extending digital competencies (Yadav \& Gulati (2019)).

In-depth study of basic models of economic development proves the need to study models of regional development, their typification of evolution and special features (Bhuiyan \& Ivlevs (2019)). It should be noted that some scientists understand the models of regional development as "country" models of economic development (Mmereki et. al (2020)).

At present, most scientific works focus on the study of regularities in the process of modeling of the organizational development of economic entities, in particular, the special features of alternative models of organizational development, the possibility of their adaptation to market needs and practical application (Shapiro \& Mandelman (2016)). As organizational development is one of the ways to make organizational changes, the author considers it appropriate to consider models of organizational change in more detail.

Highly appreciating the theoretical-methodological and scientific-practical contribution of the above scientists in supporting the development of business (including small business), it should be noted that a number of problematic aspects require further study. Although many scientific works focused on recording and analysis of financial results, tax regulation, the financial mechanism of small business development, etc. constant changes in the strength and sometimes the nature of the influence of various factors on the activities of small business determine the feasibility of further study of these issues. The level of validity of small business development forecasts in different scenarios of the market situation also remains unsatisfactory, insufficient attention is paid to improving the efficiency of small business, ensuring its innovation nature, rapid adaptation to change, minimizing losses from market threats, etc. 


\section{ENTREPRENEURSHIP AND SUSTAINABILITY ISSUES}

ISSN 2345-0282 (online) http://jssidoi.org/jesi/

2021 Volume 8 Number 4 (June)

http://doi.org/10.9770/jesi.2021.8.4(45)

\section{Research Methodology and Data}

Synthesis of the results of fundamental and applied research of scientists on the problem of small business development is the methodological basis of the paper. The main scientific method of study in the paper is a system one, the use of which has led to the study of bottlenecks in the development of national small business. The following general scientific methods of study were used to obtain specific scientific results: dialectical method; hypothetical-deductive method - to build the main working hypotheses of the study; inductive method - to move from the results of a scientific experiment to the development of general procedural guidelines; analytical method - to identify problematic aspects of small business development; a complex of economicstatistical and economic-mathematical methods of analysis and modeling - to identify signs of violations of the process of small business development; methods of analogy — to substantiate the main recommendations for the development of a national program for small business development.

Scientific works of scientists, laws and regulations of the Verkhovna Rada of Ukraine and the Cabinet of Ministers of Ukraine, data of the State Statistics Service of Ukraine, data of financial reports of small business entities, results of own studies of small business development were the information base of the paper.

The following hypotheses were suggested and tested during the study:

1) Reduction to a certain level of the number of current regulatory legal acts governing and regulating the economic activity of small business entities and permitting documents has a positive effect and can be considered as one of the measures for the development of small business;

2) Small business entities such individual entrepreneurs can receive additional synergetic effect as a result of their economic activity, which depends on a combination of three parameters: the number of economic activities, the amount of income and the level of tax burden, which directly affect the results of their economic activities;

3) There is a certain marginal level of profitability, after which it is advisable for small business entities to move a simplified system of taxation. Data on the existence of this level create the preconditions for cost-effective development of a small business entity (SBE).

The purpose of the paper is to develop theoretical-methodological foundations, scientific-methodical and practical recommendations for the development of small business in Ukraine.

\section{Results}

In most countries, small business is considered as a driving force and a key resource for economic growth, but in Ukraine the problems of small business entities are still not given due attention, as evidenced by the low level of GDP generated by small business (about 16\%) (Government applies prudent food price stabilization policy (2021)).

It should be noted that the share of small and medium-sized enterprises (SMEs) (aggregated statistics for Ukraine provides for the generalization of information on small and medium-sized enterprises) in value added by industries ranges from $45 \%$ to $100 \%$. As of 2019, the lowest share of SMEs in value added was noted in industry (45\%), and the highest share - in agriculture (97\%). In agriculture, a significant share of SMEs is due to the specifics of agricultural holdings, most of which are registered as several limited liability companies). The highest share of SME in value added was also noted in financial and insurance sectors (98\%) and other services (100\%) (Economic stimulus program for overcoming the consequences of the COVID-19 epidemic (2021)).

As of the end of 2019, there were 1,922,978 small enterprises, which corresponds to $99.04 \%$ of all business entities in Ukraine, and specifically $96.93 \%$ were represented by micro-enterprises (Figure 1). However, in 2019, the number of small enterprises decreased by $11.06 \%$ compared to 2010 . During the analysis period, the lowest 
number of small enterprises was noted in 2012 amounting to 1,578,878 enterprises, which is less than in 2010 by $27 \%$.

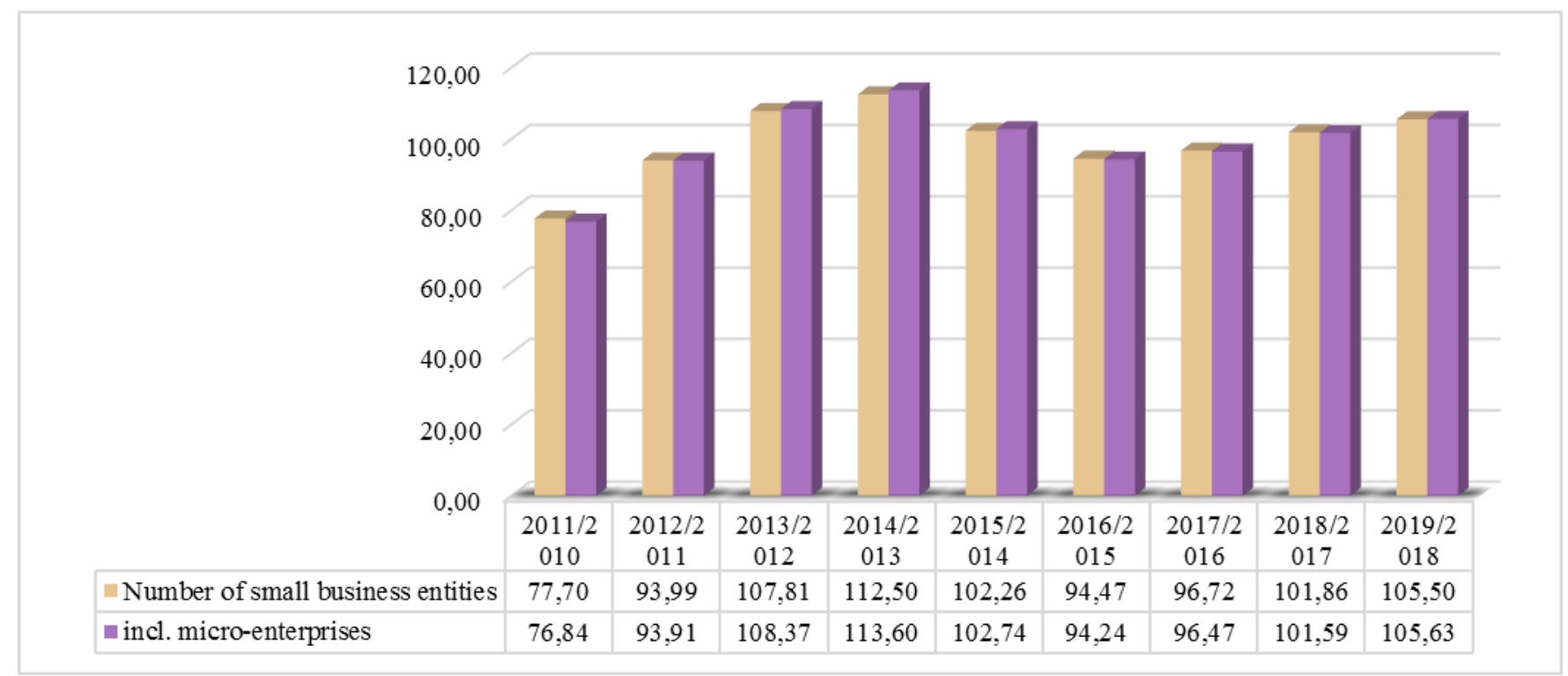

Fig. 1. Relative growth rate of the number of small enterprises, including micro-enterprises in Ukraine during 2010-2019, \% Source: author's calculations based on the data from the official website of the State Statistics Service of Ukraine (2021)

It should be noted that in 2019, $81.16 \%$ of small business entities carried out economic activities without the formation of a legal entity, i.e., chose an individual entrepreneur (FOP) as the organizational and legal form of economic activity (Figure 2).

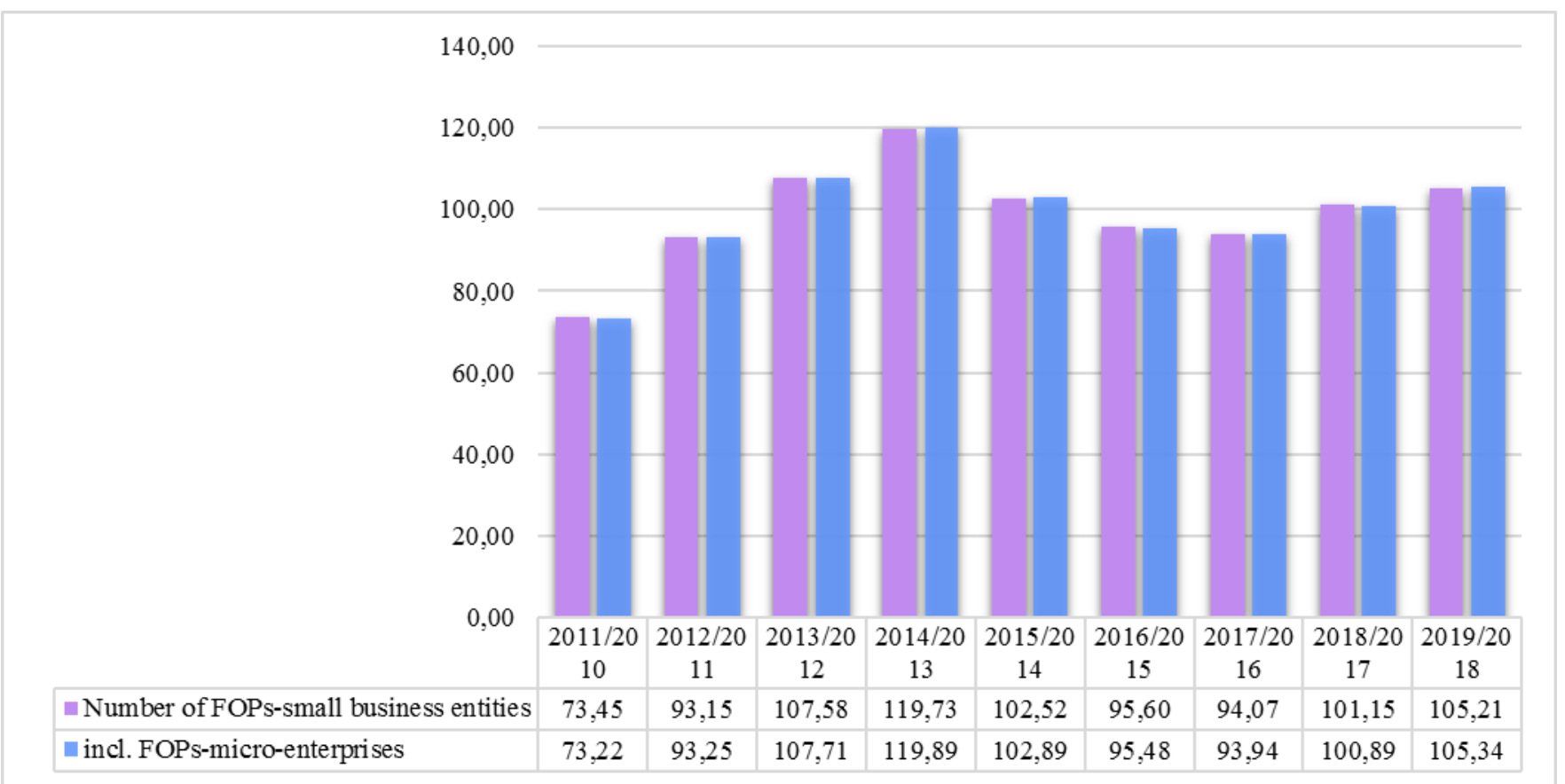

Fig. 2. Relative growth rate of the number of individual entrepreneurs, small business entities, including micro-enterprises in Ukraine during 2010-2019,\%

Source: author's calculations based on the data from the official website of the State Statistics Service of Ukraine (2021) 
At the same time, the number of FOPs is similar to the total of SBEs. Their number also decreased by $13.53 \%$ over 10 years. In 2019, the total number of individual entrepreneurs, small business entities, in Ukraine was 1,560,650 persons (this figure corresponds to $80.4 \%$ of all business entities) and specifically 1,550,633 FOPs were represented by micro-enterprises, which corresponds to $99.36 \%$ of all FOPs and $79.86 \%$ of the total number of SBEs. In 2019, the number of individual entrepreneurs engaged in retail and wholesale trade (this type of economic activity is predominant in the structure of FOPs by type of economic activity) was 732,571 persons, which corresponds to $47 \%$ of the total number of FOPs.

However, the volume of products sold by small business entities and individual entrepreneurs in the country in 2019 was insignificant and amounted to UAH 858,337,498.2 thousand, which corresponds to $8.16 \%$ of the total volume of products sold by all business entities in Ukraine. It should be noted that the share of products sold by FOPs and SBEs in the period from 2010 through 2019 fluctuated within $4.8 \%$ (in 2011)-8.16\% (in 2019), demonstrating a growth trend and reaching the maximum value for 10 years in the last reporting period (Figure 3).

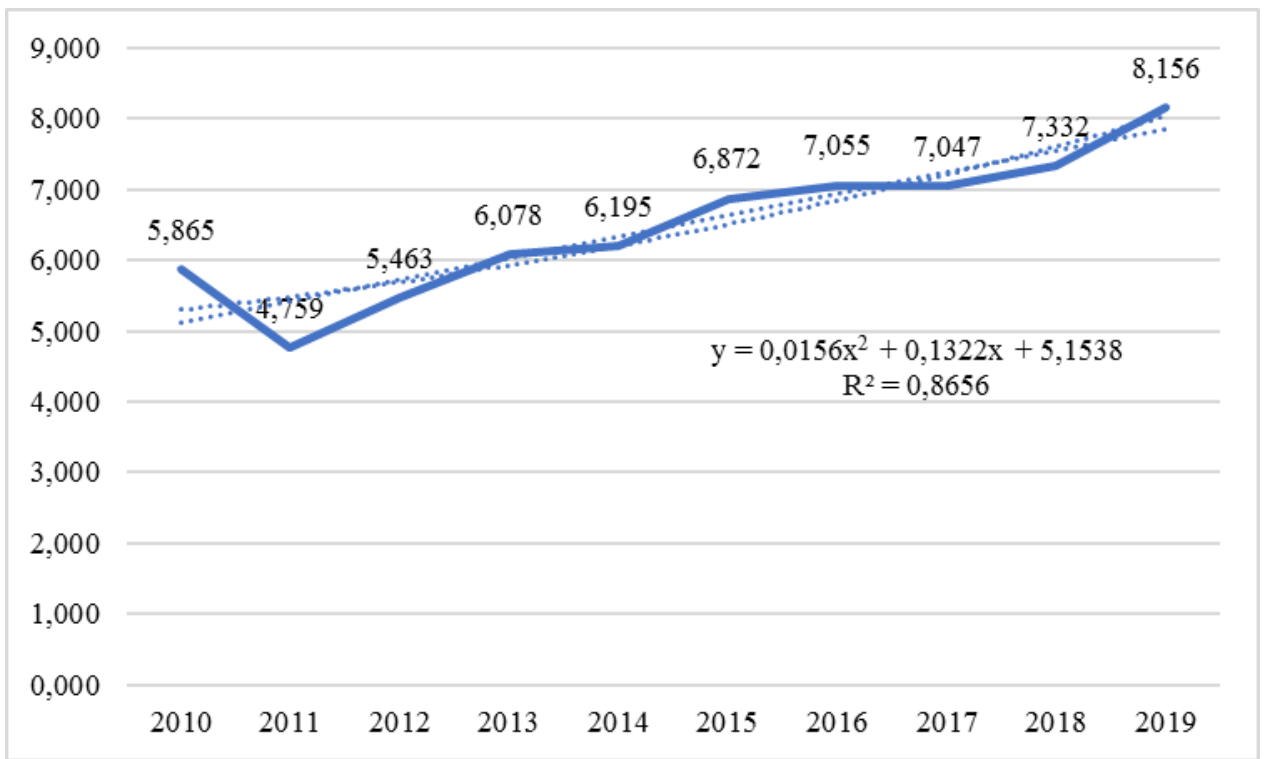

Fig. 3. Share of the volume of products sold by FOPs and SBEs in the volume of products sold by all business entities (\%), taking into account the polynomial trend

Source: author's calculations based on the data from the official website of the State Statistics Service of Ukraine (2021)

Individual entrepreneurs provide jobs for more than $2.5 \mathrm{mln}$ ppl per year. As of 2019, the number of people employed by individual entrepreneurs- SBEs corresponded to 2,573,183 persons, including 1,280,252 persons employed by individual entrepreneurs engaged in wholesale and retail trade, which amounted to $49.8 \%$ of all employees employed by individual entrepreneurs-SBEs.

During 2010-2019, the number of SBEs-legal entities (small enterprises and micro-enterprises) remained almost unchanged relative to the baseline indicator of 2010. In 2019, the number of small enterprises decreased by $1.01 \%$, and micro-enterprises - by $1.04 \%$ compared to the baseline indicator (Figure 4). 


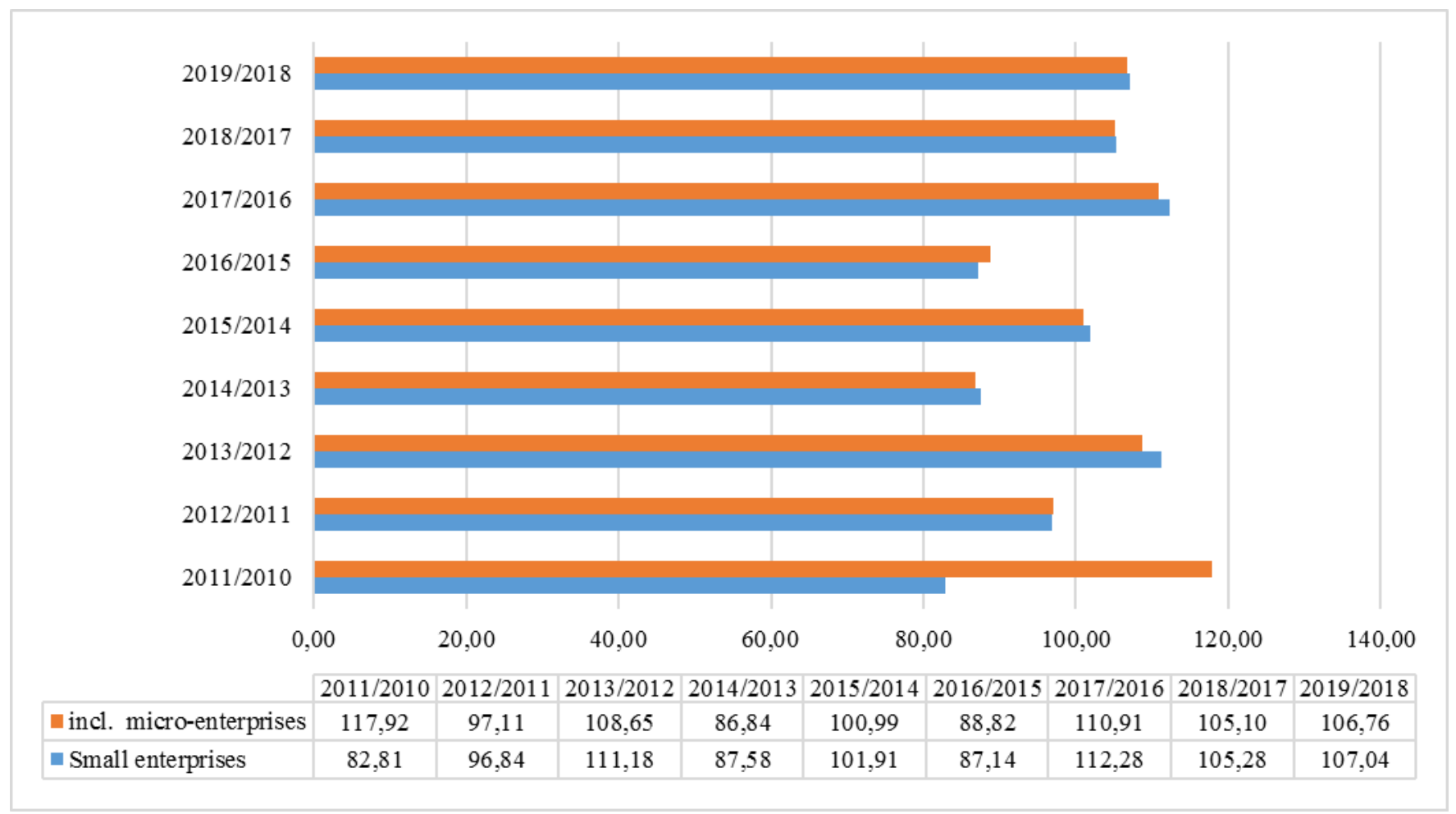

Fig. 4. Relative growth rate of the number of small business enterprises-legal entities in Ukraine during 2010-2019, \% Source: author's calculations based on the data from the official website of the State Statistics Service of Ukraine (2021)

At the same time, over the last four years from 2016 through 2019, the number of micro-enterprises-legal entities increased by 65.69 thousand or $26.5 \%$ against the background of a slight increase in their share in the number of small enterprises compared to the same indicator of 2016. It should be noted that in 2019 the share of microenterprises in the number of small enterprises $(86.5 \%)$ almost reached the maximum figure for the decade, which was noted in 2015. As of 2019, in Ukraine the share of micro-enterprises in the total number of legal entities amounted to $82.34 \%$, which is $1.5 \%$ higher than in 2016. Accordingly, in 2019, the share of small enterprises in the total number of legal entities was $95.2 \%$, which is only $0.16 \%$ higher than in 2016 . The above data indicate the relative stability of the structure of SBEs-legal entities in Ukraine during 2016-2019 with a slight shift in priorities in favor of micro-enterprises. This trend is explained by the objective advantages of starting and organizing the activities of a micro-enterprise.

The number of employees in small business entities tends to decrease over the last decade (Figure 5). The highest indicator of official employment in small business entities amounting to 4,958.6 thousand persons was recorded in 2010. The lowest employment in small business entities was noted in 2015 and has increased slightly since then. In general, the indicator of 2019 is at the level of $87.1 \%$ of the indicator in 2010 , which is due not only to the real decline in employment in small business entities, but also the informal employment of part of personnel. In the period from 2010 through 2019, the number of employees in SBEs decreased to 4,958,609 persons. According to World Bank's International Labor Organization, the level of informal employment in Ukraine is between 2 and 4.7 million persons. In fact, this is from 14 to $33 \%$ of officially employed. 
ENTREPRENEURSHIP AND SUSTAINABILITY ISSUES

ISSN 2345-0282 (online) http://jssidoi.org/jesi/

2021 Volume 8 Number 4 (June)

http://doi.org/10.9770/jesi.2021.8.4(45)

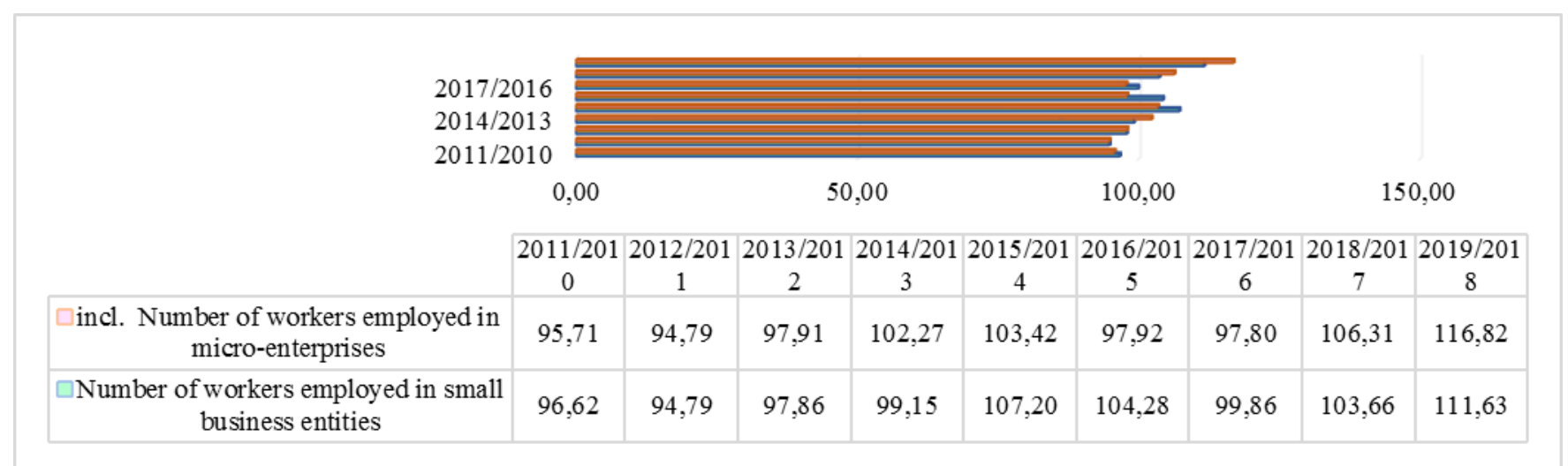

Fig. 5. Relative growth rate of the number of employees in small enterprises and micro enterprises in Ukraine during 2010-2019, \% Source: author's calculations based on the data from the official website of the State Statistics Service of Ukraine (2021)

In Ukraine, small business entities are an underestimated reserve for employment growth both due to the increase in the number of self-employed persons and due to the jobs they create. It should be noted that the number of hired workers in SBEs over the past 10 years has decreased and in 2019 amounted to $85.6 \%$ of the value of 2010, which corresponds to the value of 2,595,848 persons. The number of employed workers has also decreased over the years of the study. This indicator had the lowest value in 2015. As of the end of 2019, the number of employed workers in micro-enterprises corresponded to $87.4 \%$ of the value of 2010 .

It should be noted that statistical information on small business entities has not been provided in full on the website of the State Statistics Service of Ukraine since 2018. Most of the data presented relate to small enterprises-legal entities (small enterprises and micro-enterprises), which conditioned the specifics of information provisions, in particular, personnel costs, wages costs and contributions to social activities of Ukrainian small enterprises and micro-enterprises for 2018.

The conducted diagnostics of the state and dynamics of national small business confirmed the presence of negative trends, namely: reduction of the number of small business entities including micro-enterprises during 2010-2019; reduction of the number of individual entrepreneurs-small business entities during 2010-2019; uneven distribution of small business entities by regions as of the end of 2019; distortion of the structure of small business entities by type of economic activity and by volume of products (goods, services) sold by small business entities in favor of certain types of economic activity, including wholesale and retail trade (about $50 \%$ ) in 2019; reduction of the number of employed workers in small business entities during 2010-2019; growth of the level of expenses of small business entities in Ukraine during 2010-2019; the presence of $26.7 \%$ of unprofitable small enterprises and $27.9 \%$ of micro-enterprises of their total number in 2019; lower than the average level of profitability of operating and all other activities of small enterprises during 2017-2019; unprofitable economic activity of small enterprises during 2010-2017 and micro-enterprises during 2010-2018; almost twice lower growth rates of own capital of small enterprises compared to the growth of own capital of large enterprises in Ukraine in 2019.

Small business plays a key role in the economy of the country, and at the same time suffers the most from the effects of negative factors, in particular, from the crisis caused by the COVID-19 pandemic. As a result of the restrictions established during the quarantine, the following negative effects took place: some sectors have not been able to function properly due to the ban on doing business; traffic restrictions have complicated the logistics of workers; falling incomes of the population. As of May 27, 2020, during the quarantine period the gross value added of SMEs in the hotel and restaurant business and in the field of education and culture decreased by more than $90 \%$, and in wholesale and retail trade and in the area of provision of professional and administrative 


\section{ENTREPRENEURSHIP AND SUSTAINABILITY ISSUES}

ISSN 2345-0282 (online) http://jssidoi.org/jesi/

2021 Volume 8 Number 4 (June)

http://doi.org/10.9770/jesi.2021.8.4(45)

services - by $45 \%$. Employment by sectors in small and medium-sized enterprises decreased by $4 \%-41 \%$ (the largest decrease in employment was in the hotel and restaurant business).

According to the State Fiscal Service, the amount of taxes paid decreased by $40 \%-80 \%$ in some sectors. The largest losses by the amount of taxes are noted in wholesale, retail trade and industry, and by the share of uncollected taxes - in education and culture $(-77 \%)$ and hotel and restaurant business (-81\%) (Official website of the State Statistics Service of Ukraine (2021)). It should be noted that as a result of the economic downturn worldwide due to coronavirus disease, national small business entities have limited sales opportunities, which negatively affects their economic activities.

\section{Discussion}

Activation of structural rebuilding of the economy, performance of a number of important functions on diversification and adaptation of production. Traditionally, entrepreneurs set the direction of economic growth. This primarily applies to services provided to the population: personal, trade, tourist, business services: consulting, marketing, engineering, etc (Martínez et. al (2018)). In the above sectors, small business entities fill the niches, which are not coved by large and medium-sized business entities. This is relevant for both foreign and national small business entities.

World experience (Sohns \& Diez (2018)) proves the high efficiency of small business, which is achieved through specialization, the ability to produce goods needed by the market, to meet the needs in scarce services, to manufacture custom products. Small business entities are completely independent in carrying out economic activities, have all the capabilities to ensure the management of production, supply, and sales on the basis of simple organizational structures with a minimum number of administrative staff (Halim et. Al (2014)).

However, Ukrainian SBEs are characterized by low efficiency of economic activity, which is confirmed by the results of research. At the same time, they are characterized by the low indicator of labor productivity, which is due to the low level of automation and mechanization of production processes, as well as a small share of SBEs that use the latest technologies; significant energy intensity (exceeding world indicators by 2.5-3 times) and material and material intensity of production in Ukraine (exceeding world indicators by $2-2.5$ times).

Small business entities around the world are characterized by mobility, as the lack of significant investment allows them to respond more quickly to changes in market conditions and develop unclaimed segments (Mondal $\&$ Jimenez (2015)). This feature is due to the nature of small business entities and low total value of assets at their disposal.

There is ample evidence that small business-dominated communities are socially stable, actively involved in the electoral process, attract more tourists to the region, and support more enterprises (Bögenhold \& Klinglmair (2015)). Another positive aspect of small business is the local concentration of funds and, respectively, the growth of local economic indicators. As a result, there is an increase in the well-being of the local population, the number of jobs and tax revenues to the budget.

The above indicates the great political importance of small business. This is relevant for many developed countries, as entrepreneurs as a social group are the basis of the middle class, the most representative in number and one that expresses the political preferences of a large part of the population.

In the context of sustainable socio-economic and political development of society, small business entities are distinguished by the commitment to the principles of democracy, political stability and economic freedom. They are most active when there is a threat to property, as, in contrast to large and medium-sized owners, for small 


\section{ENTREPRENEURSHIP AND SUSTAINABILITY ISSUES}

ISSN 2345-0282 (online) http://jssidoi.org/jesi/

2021 Volume 8 Number 4 (June)

http://doi.org/10.9770/jesi.2021.8.4(45)

business entities their property, for the most part, is the main source of livelihood and the most important means of self-expression.

Ukrainian small business entities display high resilience to adaptation to market conditions due to the increased complexity and dynamism of the latter. In countries with developed market economies, SBEs operate mainly in a stable external environment and are less adapted to its changes due to lack of experience of adaptation (Hall et. Al (2019)).

It should be noted that in Ukraine recently there have been positive changes in the area of determining the strategic priorities of national small business, which aims to ensure access to the trajectory of sustainable socioeconomic development not only of this stratum of economic entities, but also the economy as a whole. By the Resolution of the Cabinet of Ministers dated May 24, 2017 No. 504-p. there was approved the "Strategy for Small and Medium-sized Enterprise Development in Ukraine until 2020" (On Approval of the Strategy for Small and Medium-sized Enterprise Development in Ukraine until 2020 (2017)), which was developed taking into account the main provisions of the current regulations.

In addition to the above regulatory legal acts, which served as the basis for developing the strategy for small and medium-sized enterprise development in Ukraine, the Law of Ukraine "On Development and State Support of Small and Medium-Sized Enterprises in Ukraine" With amendments (2012)) approved within the framework of the Association Agreement between Ukraine and the European Union is also the legal basis for small business development.

The starting point for the development of the strategy for small business development can be the creation of a project office for the development and implementation of the strategy — the Small Business Development Center, which will: coordinate and support the actions of all institutions engaged in the process of strategic management.

\section{Conclusions}

Thus, we can draw a conclusion that small business is not isolated from the general economic system, but is an integral part of it, which is organically introduced into modern economic practice. It is small business that contributes to the formation of the market as a result of the revival of closed and the creation of new industries, the development of tangible and intangible resources, expanding the scope of innovation.

The study of the development of national small business in dynamics over the last 9 years, which is based on official statistical information, proved the presence of negative trends, namely: reduction of the number of small enterprises and micro-enterprises, reduction of the number of individual entrepreneurs-SBEs, distortion of the structure of SBEs by type of economic activity and volume of products sold, reduction of the number of employed and hired workers in SBEs, increase in the share of expenses of SBEs in the total expenses of business entities, total negative balance of the financial result of SBEs, etc.

The studies of small business development based on statistical information, analysis of financial and property condition of SBEs, sample author's studies and observations allowed to define the features of national small business: tendency to intensification of the structural rebuilding of the economy, functions of diversification and adaptation of production; low efficiency of economic activity, which growth can be achieved through specialization; mobility, quick response to changes in the market situation; special attitude to the labor process; ability and willingness to innovate; availability of necessary organizational skills; social orientation. 


\section{ENTREPRENEURSHIP AND SUSTAINABILITY ISSUES}

ISSN 2345-0282 (online) http://jssidoi.org/jesi/

2021 Volume 8 Number 4 (June)

http://doi.org/10.9770/jesi.2021.8.4(45)

\section{References}

Ahsan, M. (2020). Entrepreneurship and ethics in the sharing economy: A critical perspective. Journal of Business Ethics, 161(1), 19-33. Retrieved from: https://link.springer.com/article/10.1007/s10551-018-3975-2

Bhuiyan, M. F., \& Ivlevs, A. (2019). Micro-entrepreneurship and subjective well-being: Evidence from rural Bangladesh. Journal of Business Venturing, 34(4), 625-645. Retrieved from: https://www.sciencedirect.com/science/article/pii/S0883902617306341

Bögenhold, D., \& Klinglmair, A. (2015). Micro-entrepreneurship: tendency towards precarious work? empirical findings for austria. Athens Journal of Economics and Business, 1(2), 107-121.

Galvão, A. R., Mascarenhas, C., Marques, C. S., Braga, V., \& Ferreira, M. (2020). Mentoring entrepreneurship in a rural territory-A qualitative exploration of an entrepreneurship program for rural areas. Journal of Rural Studies, 78, 314-324. Retrieved from: https://www.sciencedirect.com/science/article/abs/pii/S0743016719312100

Government applies prudent food price stabilization policy (2021). Website of the Ministry for Development of Economy, Trade and Agriculture of Ukraine. Retrieved from: https://www.me.gov.ua/?lang=uk-UA

Economic stimulus program for overcoming the consequences of the COVID-19 epidemic (2021). Government portal. The single web portal of the executive authorities of Ukraine. Retrieved from: https://www.kmu.gov.ua/news/uryad-zatverdiv-z-

doopracyuvannyam-programu-stimulyuvannya-ekonomiki-dlya-podolannya-naslidkiv-epidemiyi-covid-19

Halim, M. A. S. A., Zakaria, Z., Hamid, A. C., \& Khalid, M. K. A. (2014). Fostering micro-entrepreneurship as panacea to poverty eradication in the Malaysian economy: A conceptual perception. Asian Social Science, 10(13), 287.

Hall, K., Needham, C., \& Allen, K. (2019). Micro entrepreneurship in the care sector: motives, values and practices. Voluntary Sector Review, 10(3), 311-328. Retrieved from: https://www.ingentaconnect.com/content/tpp/vsr/2019/00000010/00000003/art00004

Karlan, D., \& Valdivia, M. (2011). Teaching entrepreneurship: Impact of business training on microfinance clients and institutions. Review of Economics and statistics, 93(2), 510-527. Retrieved from: https://direct.mit.edu/rest/article/93/2/510/58592/Teaching-Entrepreneurship$\underline{\text { Impact-of-Business }}$

Kimmitt, J., \& Munoz, P. (2017). Entrepreneurship and financial inclusion through the lens of instrumental freedoms. International Small Business Journal, 35(7), 803-828. Retrieved from: https://journals.sagepub.com/doi/abs/10.1177/0266242617700699

Martínez A, C., Puentes, E., \& Ruiz-Tagle, J. (2018). The effects of micro-entrepreneurship programs on labor market performance: experimental evidence from Chile. American Economic Journal: Applied Economics, 10(2), 101-24. Retrieved from: https://www.aeaweb.org/articles?id=10.1257/app.20150245

Mmereki, D., Hovorka, A., \& Gwebu, T. (2020). A gender analysis of micro-entrepreneurship in developing-transition countries: insights from Botswana. International Journal of Entrepreneurship and Small Business, 39(3), 395-429. Retrieved from: https://www.inderscienceonline.com/doi/abs/10.1504/IJESB.2020.104986

Mondal, W. I., \& Jimenez, L. (2015). Teaching Entrepreneurship And Micro-Entrepreneurship: An International Perspective. Journal of International Education Research (JIER), 11(3), 189-196. Retrieved from: https://www.clutejournals.com/index.php/JIER/article/view/9370

Official website of the State Statistics Service of Ukraine (2021). Retrieved from: http://www.ukrstat.gov.ua/

On Development and State Support of Small and Medium-Sized Enterprises in Ukraine. With amendments (2012). Resolution of the Verkhovna Rada No. 4618-IV, January 11, 2012. Retrieved from: https://zakon.rada.gov.ua/laws/show/4618-17\#Text

On Approval of the Strategy for Small and Medium-sized Enterprise Development in Ukraine until 2020 (2017). Resolution of the Cabinet of Ministers of Ukraine No. 504, May 25, 2017. Retrieved from: https://zakon.rada.gov.ua/laws/show/504-2017-p\#Text

Senapati, A. K., \& Ojha, K. (2019). Socio-economic Empowerment of Women Through Micro-entrepreneurship: Evidence from Odisha, India. International Journal of Rural Management, 15(2), 159-184. Retrieved from: https://journals.sagepub.com/doi/abs/10.1177/0973005219866588 


\section{ENTREPRENEURSHIP AND SUSTAINABILITY ISSUES}

ISSN 2345-0282 (online) http://jssidoi.org/jesi/

2021 Volume 8 Number 4 (June)

http://doi.org/10.9770/jesi.2021.8.4(45)

Shapiro, A. F., \& Mandelman, F. S. (2016). Remittances, entrepreneurship, and employment dynamics over the business cycle. Journal of International Economics, 103, 184-199. Retrieved from: https://www.sciencedirect.com/science/article/abs/pii/S0022199616301143

Sohns, F., \& Diez, J. R. (2018). Explaining micro entrepreneurship in rural Vietnam - a multilevel analysis. Small Business Economics, 50(1), 219-237. Retrieved from: https://link.springer.com/article/10.1007/s11187-017-9886-2

Vial, V., \& Hanoteau, J. (2015). Returns to micro-entrepreneurship in an emerging economy: A quantile study of entrepreneurial Indonesian households' welfare. World Development, 74, 142-157. Retrieved from: https://www.sciencedirect.com/science/article/abs/pii/S0305750X15000923

Vigliarolo, F. (2020). Economic phenomenology: fundamentals, principles and definition. Insights into Regional Development, 2(1), 418429. http://doi.org/10.9770/IRD.2020.2.1(2)

Yadav, J., \& Gulati, N. (2019). SWOT Analysis of Micro Entrepreneurship and Start-ups in Haryana. International Journal of Business and Economics Research, 8(6), 399. Retrieved from: http://article.ijober.org/pdf/10.11648.j.ijber.20190806.20.pdf

Kazimierz PAJAK, Ph.D., Habilitated Doctor in Economics, Professor, Institute for International Cooperation Development, Poland ORCID ID: orcid.org/0000-0002-4668-0449

Viacheslav VOLIK, Doctor of Law, Professor, Professor of the Law and Public Administration Department, Mariupol State University ORCID ID: orcid.org/0000-0002-1344-9486

Iryna SLOVSKA, Doctor of Law, Phd, Professor of the Constitutional Law and Branch Disciplines Department, National University of Water and Environmental Engineering

ORCID ID: orcid.org/0000-0001-9587-2300

Yuliia LUSHCHYK, PhD in Educational Sciences, Senior Lecturer of Foreign Languages Department, Sumy National Agrarian University

ORCID ID: orcid.org/0000-0003-4306-1949

Hanna TSYHANOK, PhD in Philological Sciences, Senior Lecture of Foreign Languages Department, Sumy National Agrarian University

ORCID ID: orcid.org/0000-0003-6303-6831

Make your research more visible, join the Twitter account of ENTREPRENEURSHIP AND SUSTAINABILITY ISSUES: @Entrepr69728810

Copyright (C) 2021 by author(s) and VsI Entrepreneurship and Sustainability Center

This work is licensed under the Creative Commons Attribution International License (CC BY).

http://creativecommons.org/licenses/by/4.0/

C) (i) Open Access 